\title{
The Newars of the Hills: Migration and Adaptation
}

\author{
Shrestha Khadga Narayan, PhD
}

\begin{abstract}
This paper discusses on the emigrated Newars from Kathmandu Valley to different parts of Solududhkunda Municipality. The paper explores the origin and migration of the Newars and tries to analyze how the emigrated Newars united each other; and socially and culturally adapted through social organizations such as guthi and samaj. The nature of this paper is qualitative. Semistructured interviews, group discussions and key informants' interviews were the major tools for data collection. The genealogies of the Newars were reviewed to analyze their out-migration process. However, the causes of their out-migration from the Kathmandu Valley was not clear but trade, kinship, forced migration and local disputes may be the probable causes of their outmigration. The establishments of guthi or samaj are very much important to the Newars to adjust in the new socio-cultural environments. The guthi or samaj not only fulfilled their socio-cultural and economic needs but also showed their joint strength and power to cope with other caste and ethnic groups. Giving membership to non-Newar families and attending Buddhists ceremonies as stakeholders, accepting Hindu Brahmin as their priest and acculturation are the adapting strategies of the Newars in the new circumstances. However, remigration of the educated and capable Newar youths is the major questions for their existence in the Solu-dudhkunda Municipality.
\end{abstract}

Key words: Newar, out-migration, socio-cultural adaptation, guthi or samaj, acculturation

\section{Background}

Newar is one of the ethnic groups of Nepal (Nepali, 1965). They are the indigenous people of Kathmandu Valley. But today the Newars stay in almost all districts of Nepal. The unique cultural practices, feast and festivals, rituals and rites, jatra and parva created a distinct identity of the Newars. Although the Newars are rich in their culture and tradition, their population is only 5.4 per cent in Nepal (CBS, 2012). Many scholars stated that Kathmandu Valley was the origin of the Newars (Hamilton, 1819; Wright, 1877; Nepali, 1965; Bista, 1967) and describes them as peaceful and cheerful business people (Nepali, 1965). Wright (1877) mentions the Newar's settlement, appearance, and occupations. He writes:

The Newars constitute the largest section of the inhabitants of the valley but are not numerous beyond its limits. They were the occupiers of the country prior to the invasion of the Gorkhas....They are in general a shorter set of men than Gorkhas, and 
their features are more of the Mongolian type. They perform almost all the types of agricultural and mechanical work....Most of the trade of the country too is in the hands of Newars, and a few of them are very wealthy (p. 26).

In regard to the origin and history of the Newars, scholars unanimously claim that they were intermixed of multiple caste and ethnic groups (Nepali, 1965; Bista, 1967). It is told that the Newars are the intermixed community racially, facially and culturally. It is because by the time of the invasion, the defeaters in Nepal Valley was biologically and culturally intermixed and became the Newars (Sharma, 2039 B.S.). However, Bista (1967) states:

They (Newar) are small shopkeepers, big businessmen, importers, exporters, farmers, craftsmen and so on....The term Newar itself was derived from the name of country, or vice versa. When we refer to Nepal in association with just the Newar people we usually mean only the Nepal valley, Kathmandu valley (p. 19).

Lewis and Shakya (1988) have also same views on the Newars. They stated that "Newar society was known for its literate elite, successful businessmen, talented artists, and skilled agriculturalists” (p. 29).

There is no doubt that the Newars were the early settlers of Kathmandu Valley. They were not only skilled farmers but also good traders. Trade and the Newars cannot be understood separately. The Newars are settled everywhere even in the small haat bazar, streets and cross roads.

This paper discusses on the emigrated Newars from Kathmandu Valley to different parts of Solu-dudhkunda Municipality. Although the term 'adaptation' is frequently used in the paper, I focused to analyze how the emigrated Newars united and adjusted socially and culturally through social organizations such as guthi and samaj rather than analyzing their ecological adaptation. I also argue that the Newars' acculturation and intra-cultural variations are to be understood and analyzed through their social and cultural adaptation in relations to the non-Newars communities such as the Sherpa and the Chhetri..

However, the paper aims to explore the causes of out-migration of the Newars from Kathmandu Valley in general. But, the main thrust of the paper is to analyze the origin, migration and socio-cultural adaptation of the Newars in Solu-dudhkunda Municipality through different guthis and samaj.

\section{Methods and Materials}

The nature of this paper is qualitative. I applied semi-structured interview with the Newars residing in both Solu-dudhkunda Municipality and re-migrated Newars from the municipality who are currently living at the different places of Kathmandu Valley. The 
study is based on both primary and secondary sources. Published and unpublished genealogy was very much supportive to analyze the migration process. The interviews were taken with the old Newars to know the history. Some information is carried by key informant interviews and group discussions.

\section{Reasons of the Newars' out-migration from Kathmandu Valley}

Migration is a universal phenomenon. It is a movement of people from one place to another for various reasons. Migration may be forced such as refugee, victims of natural disaster or voluntary for seeking better opportunities and easy livelihood. Scholars have multiple views and ideas on the migrants' and migration (Shrestha, 2001; Adhikari, 2008; Gurung, 2001). However, both the pull and push factors play vital role for the migration of individual, family or group.

Migration is a major cause of social, cultural and economic change. Social integration, disintegration, acculturation and assimilation processes are largely depend on the migration of people. But, migration is encouraged by globalization and diffusion of Western values and life styles (Heide, 2001). However, Schneller (2001) argues that influx of international in-migrants create serious problems on integration. Migration is not only understood as the mobility of people but it is also the subject to change. The mobility and changes are to be analyzed through regional, national and international political and economic influences (Hoffmann, 2001). Some of these concepts are useful to analyze out-migration, acculturation, social and cultural adaptation and change among the Newars of Solududhkunda Municipality.

It is very hard to declare and conclude the causes of Newars' out-migration from the Kathmandu Valley. The scholars have different ideas and arguments on the matter (Lewis \& Shakya, 1988; Shrestha, 2006, 2015; Rajbhandari, 2013; Robertson, 2020). Bista (2030 B.S.) writes that the Newars were settled in the hills, the terai, the East and the West of Nepal and the trade was the prime cause of their migration rather than for holding land and farming. He states the Newars as skilled businessmen and learned local languages for the adaptation and conduction of business. His argument of migration of the Newars for nonfarming occupation is near to the truth because most of the out-migrated Newars are involved in trade rather than farming and animal herding. Their settlement towards the cities and bazar also strongly supports this argument. But his argument is too general and unable to locate the particular study area.

Similarly, Shrestha (2015) says, "the migration of the Newars from Nepal to the Himalayan Kingdom of Sikkim began in the middle of the $19^{\text {th }}$ century (p. 1)....Many Newars went exile in order to escape the torture and save their lives” (p. 4) and mentions two 
contradictory arguments of the Newars arrivals in Darjeeling and Sikkim (Shrestha, 2006). The first argument is that Laksmidas Pradhan (Kasaju), a Newar from Bhaktapur was the first Newar escaped from the Nepal valley after Kot Massacre of 1846 and the second is that he reached Sikkim for his Gundruk trade. However, Gorkha conquest (Unification of Nepal by Prithivi Narayan Shah) in Nepal Valley in 1769 A. D. was the cause of the Newars' outmigration (Pradhan, 2018). The ill behavior on the Newars by Ghorkali rulers and its continuation in different phases of time had also compelled to leave the Valley (Shrestha, 2010; Tuladhar, et al., 2011; Sakasita, 2020). Sakasita (2020) has two different arguments: the first, King Prithivi Narayan Shah's ban on the construction of new houses, and construction and renovation of temples, dhunge dhara, pati, pauwa and so on which made the Newars unemployed. Those who acted against the rules made by new King were assassinated. Hence, the Newars were compelled to leave the Kathmandu valley. The second argument was that king Rana Bahadur Shah exiled those Newar families who had small children from the valley to make the prince and royal families safe from smallpox. The author also describes the tragic death of Newar's children on the way to the outside of the valley. An American historian Robertson (2020) writes how King Rana Bahadur Shah exiled the Newar families due to the threat of smallpox:

In 1799 ....Rana Bahadur, distraught and furious, desecrates and destroys the temple of Hariti ma (known to Hindus as Sitala) at Swayambhu. Rana Bahadur also orders children with the disease removed outside the Valley, all the way across the Tama Kosi in the East or the Marsyandi in the West. Because of the Valley's demographics, these were Newar children (www.nepalitimes.com/opinion/smallpox-politics-and-power-in-kathmandu, retrieved, July 13, 2020).

The exiled families had the hardest days. It is hard to imagine of walking several days for an unknown destinations with their children. The families had lost their properties in the Valley and struggled for their fate and future. The parents not only suffered from thirst and hunger but also lost their children. Robertson (2020) writes:

Parents faced heartbreaking difficulties. 'They led them away, carrying one child on the back, one child under the arm and dragging along a third child.' After a week, the families reach the Tama kosi. There, a child dies. Unable to say goodbye the proper way, the devastated parents throw the body into the river www.nepalitimes.com/opinion/smallpox-politics-and-power-in-kathmandu, retrieved, July 13, 2020). 
The authors strongly focused on the forced migration. The statements on the Newars' out migration are partially true. But this is not a single cause for their out-migration. A unanimous argument towards the out-migration is the involvement of the Newars in trade. Regarding the out-migration, the trade with Tibet is another situation. The Nepal Valley had a trade relationship with Tibet. During the Malla period the Newars not only engaged in cross broader trades but also married with Tibetan women, get connected culturally and settled in Tibet (Bista, 1980; Lewis, 1989). Lewis (1993) states that the Newars were highly sought artisans across Tibet at least for one thousand years in Tibet.

Lewis and Shakya (1988) viewed four different reasons of out-migration; the first as state employees to supervise government mining, minting, weaving and other types of production. The second was grabbing the trade opportunities, due to new administrative network. The third, military conquest and fled of aristocrats and military after losing with Gorkhas and the fourth was the local disputes and economic obligations. However, Rajbhandari (2013) has six different perspectives on the subject. He concludes that business opportunities, invitation of petty states, conquest of Muslim and Englishmen, health hazards, government employments and kinship. Although his arguments are quite interesting, it is too general. He was unable to cite particular cases and references to support his arguments.

However, no concrete evidences are found about the out-migration of the Newars currently residing in Solu-dudhkunda Municipality. That said, we are compelled to believe on any one of the above causes of out-migration of the Newars or to believe on the informants' statements. Now, I move towards the Newars of the Solu-dudhkunda Municipality.

\section{The Newars of Solu-dudhkunda Municipality}

The municipality consists of multiple caste and ethnic groups such as Sherpa, Newar, Chhetri, Magar, Rai, Kami, Damai and so on. This study is based on the Newar people of ward number six and seven of the municipality. The total Newar population in the district is 2.45 per cent but there is 6.12 per cent Newar in the municipality (Central Bureau of Statistics-CBS, 2012). The population of the Newar is comparatively much in the municipality than other rural municipalities. It may be because the district- headquarterSalleri bazar and Phaplu airport belong within the municipality; and also because the Newars always seek a suitable place for the shops and trades.

As said above, the Newars stay at the bazar and nearby of it due to the shops and trades. The Newar of Solu-dudhkunda Municipality has settled in five main clusters i.e., DorpuSalleri bazar, Loding, Garma, Najing and Bhittakharka villages. Among these clusters, Dorpu-salleri is the main bazar of Solukhumbu district and the population of the Newar is 
higher than the other clusters. The households of Rajbhandari are more than other Newars such as Shrestha, Sakya and Kayastha. Loding consists of both Rajbhandari and Shrestha. However, Shrestha settled in Garma, Najing and Bhittakharka. Although the Newars of the municipality were migrated from different places of Bhojpur, Khotang, Okhaldhunga and Ramechhap districts, their ancestors were moved from the Kathmandu Valley.

A map of Solu-dudhkunda Municipality

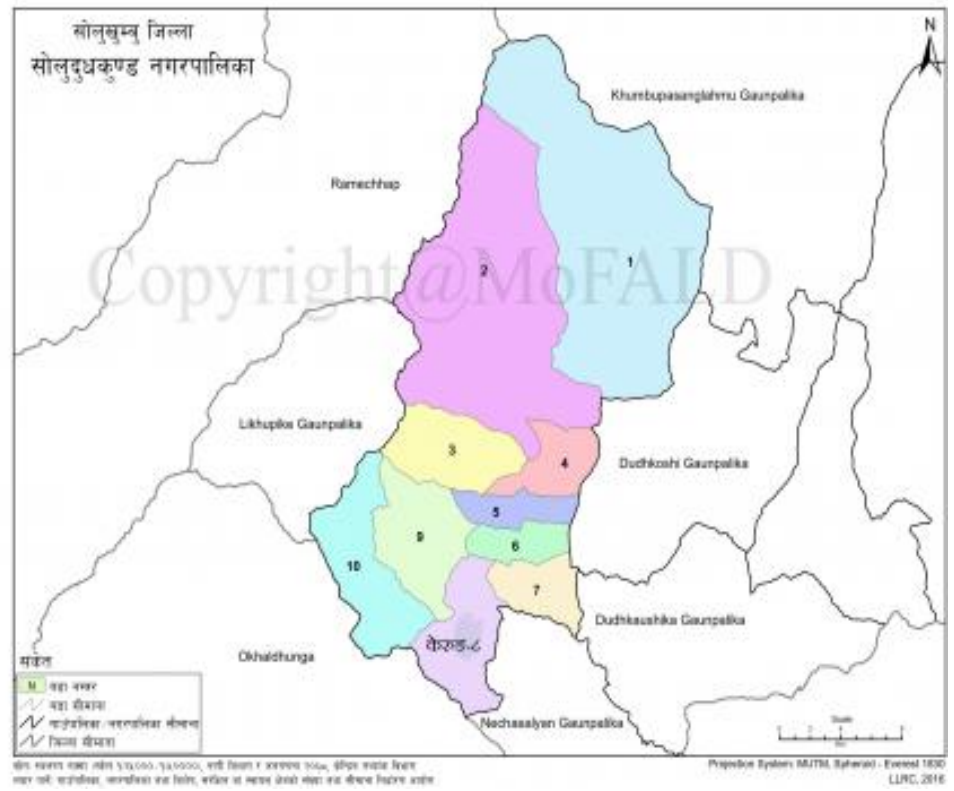

Source: www. solududhkunda.mun.gov.np

The genealogy shows that the Bolakshe of Bhaktapur was the homeland of Rajbhandri. Later, some of them moved to the East Okhaldhunga, the West Pokhara and Baglung (Rajbhandari, 2013). The genealogy details on the Rajbhandari of Nepal based on the early four clusters, i.e., Bhaktapur, Okhaldhunga, Pokhara and Baglung. It reveals that Thakur Narsingh Rajbhandari moved to Katunje of Okhaldhunga in 1868 B.S. who was the real ancestors of Rajbhandari of Okhaldhunga, Khotang and Solukhumbu (p. 75). But actual cause of his migration was unknown. When asked about the causes of migration, 70 year old I. Rajbhandari states:

We do not know the actual cause of the migration of our ancestors. But it was told that they were unable to organize bhoj (feast) in the Valley. The failure of organizing the feast frequently was guilt. Social pressure and low economic condition may push our ancestor to leave the Valley (Mr. I. Rajbhandari, personal communication, July $15,2020)$ 
Obviously, the Newars in the Kathmandu Valley perform several feast and festivals, jatras and parvas till now. Not a single month is without bhoj. The lower class and low income Newars are still in crisis. The Newars are slicing and selling their ancestral land for several reasons. This is how the statement of Mr. Rajbhandari may be close to reality.

The ancestors of the Shrestha were out-migrated from Bhaktapur and Patan. There are some evidences of Newars' migration from Patan (Lewish \& Shakya, 1988). They mention the migration of Newar in Taksar and Chainpur of Bhojpur district. They write that "this town (Taksar-Bhojpur) of roughly one thousand inhabitants had its modern genesis when the Rana government (during the rule of King Girvanayuddha Vikram Shah) opened a mint in 1814 near a copper mine and employed Newars from Patan to manufacture coins” (p. 35).

But in the cases of Shrestha's migration, there is no relevant evidence and informant's statement which proof their migration from Bhojpur to Solukhumbu. Ancestors of some Shrestha families were migrated from Bhaktapur to Salle of Khotang district and again moved to Solukhumbu. A member of such a family, 60 year old, D. Shrestha tells:

My father told me that our ancestors moved from Ilakhe of Bhaktapur to Salle of Khotang. My father married with my mother in Solukhumbu. I was born at Salle. We moved from Salle to Solukhumbu in 2018 B.S. My Thulo Buwa (father's elder brother) migrated earlier than us; when he married with a woman of SolukhumbuDorpu bazar. (Mr. D. Shrestha, personal communication, July 18, 2020).

It shows that migration is caused by kin connections. A migration through kinship relation is stated as 'strong' ties by Mark Granovetter (Childs \& Choedup, 2019). The causes of first generation out-migration from the Kathmandu Valley may be different than the migrations of onwards generations from one district to another and from one place to another.

Other families of the Shrestha, who stay at Najing, claim themselves Kasaju. The ancestor of Kasaju had migrated from Bamrang of Khotang district to Solukhumbu. Seventy eight year old Mr. N. Shrestha tells:

I know my grand grand-father Gunamanta migrated from Bamrang of Khotang. But I do not know how and when our ancestor moved to Khotang from Bhaktapur. It is almost five generations in Najing. Our new generations are migrating towards the cities of terai and Kathmandu Valley. I also stay half of the year in Damak of Jhapa district. My elder brother and my son have built houses in Damak (Mr. N. Shrestha, Personal communication, July 19, 2020).

The Newars of Solu-dudhkunda Municipality were assembled from various places and tie into the kin connections. The next group of Shrestha families was migrated from 
Ramechhap to Solukhumbu. This group claims themselves a migrant of Bhaktapur but lacks the particular date and reason of migration. However, informant of these families argues differently than others. Mr. B. Shrestha replies:

We do not know the actual cause of out-migration from Bhaktapur to Ramechhap and Solukhumbu. But I believe our ancestors were not businessmen because our early generations did not involve in any business. Of course, we have weapons that are similar of the Malla period. May be they were rulers or military at Bhaktapur. Or, it also could be that local dispute in bhoj, may push them to leave the Valley (Mr. B. Shrestha, personal communication, July 18, 2020).

There are no strong arguments to support his ideas. One of the probable causes of their outmigration is that Ramechhap is just across the Tamakoshi River. King Rana Bahadur Shah also exiled some Newar families across the Tamakoshi with their children due the health hazards; and this group of Shrestha may belong to that category.

However, the Rajbhandari and the Shrestha have affinal kin connections. It means Rajbhandari and the Shrestha can get married each other if they do not connect through matrimonial relationships. Such a kin connections may lead to the arrivals of various Shrestha and Rajbhandri inside the Solukhumbu district. The Newars of Solukhumbu like the Newars of others parts of Nepal avoid cross-cousin marriage. The concept of gotra exogamy is not applied in many cases but the Rajbhandari do not marry with the same sir name i.e., Rajbhandari.

\section{Occupation}

The Newars of the municipality are involved in various occupations. The Newars who live in bazar are dependent on the shop keeping. Some of them operated hotels and lodges. The bazar dwellers have less participated in farming and animal herding. The Newars who live at the cross-roads operate small grocery, tea shops along with farming and animal herding. The rest are engaged in the farm. The Newars are engaged in tourism activities. Some of them operated trekking companies in Kathmandu and some others are employed as guides, assistant guides, and porters and so on in trekking. Some Newars, who were migrated at the Khumbu region operated shops and bhattis (a small hut on the trekking trail to serve trekking employees, especially-the porters) on the tourists trails (Shrestha, 2020). In addition to these, the Newars are teachers and other government and non-government service holders; others go abroad for foreign employment for their economic interdependence with the Newars and the non-Newars communities. 


\section{Social and cultural organizations}

The Newars are socially and culturally bind together through guthis. Guthi as a socioeconomic institution fulfills the need of the Newars (Nepali, 1965). The guthi is associated with the identity of the Newars. The guthi or samaj are prevalent in each Newar and nonNewar clusters in Solukhumbu (Shrestha, 2018) that not only binds them together but also fulfills their socio-cultural and economic needs. Interestingly, there is no dewali guthi, sana guthi and sie guthi as practiced in Kathmandu Valley. Neither the guthi is formed within a fixed clan and caste. There is a single guthi in each cluster that handles each and every type of rituals and celebrations. The guthis are flexible for providing membership. The membership criteria allow the non-Newar families as a member of guthi. The non-Newars such as Sherpa and Chhetri were the members of the guthi. Providing membership to nonNewars and being non-Newars as member of Newar guthi indicates the ways of the Newars adaptation in different social and cultural environment and vice-versa. Such an adaptation is different than ecological adaptation stated by anthropologists such as Rappaport (1968) and Harris (1979). This is how the function and formation of guthi differ from the guthi of the Kathmandu Valley.

The names of guthi are kept after the name of their locality. The names like Dorpu guthi, Najing Bhimsen guthi and Garma guthi are some of the examples. It means guthi is not only an institution to fulfill their needs but also an identity benchmark of the people. Each Newars identify themselves with their separate guthi. The members of guthi are considered as the member of same family but not like fukee members of dewali guthi in Kathmandu (Nepali, 1965).

Each household becomes the member of the guthi. The general assembly elects executive committee for a fixed tenure. The executive committee is solely responsible for making new rules, its implementation and change. The guthi supports the member families in all rituals and celebrations when the member asks for support. There is an absence of 'Thakuli'-as guthi head and 'Thakuli-Naki' as it is in the Kathmandu Valley.

The guthi is mostly needed in death rituals. The guthi manages the dead body and handles the mourning rituals of the deceased till 12 or 13 days. The member family submits the goods or some amount of money to the family of the deceased as directed by executive committee or as a rule of the guthi. This support is obligatory. Besides, each member should look after the member of deceased family who are under the purification process turn by turn. The committee schedules for the day and night routine to look after during the funeral period. 
In addition to this, the guthi has a greater role for marriage celebration. But the invitation to guthi members is not obligatory as it is in death rituals. In the marriage ceremony, the members and non-members of the guthi offers some amount of money to the host which is called 'sarau' (The money should be returned in such a ceremony by the host). It is obligatory but the amount is not fixed as it is in the death ritual. But there are no more roles of guthi in other rituals and celebrations. The guthi is just like a committee although it handles the socio-cultural and economic activities, which are the fundamental difference with the Newars's guthi inside the Kathmandu Valley.

\section{Inclusion and exclusion of non-Newar members in the Guthi}

The guthi played a vital role for inter-caste and inter-ethnic socio-cultural adaptation in the study area. This argument is illustrated by the inclusion and exclusion of the non-Newar members in the guthi. Looking back to the history, there was some cases of the non-Newars participation or forming a guthi jointly by both the Newars and the non-Newars in Solududhkunda Municipality. However, such a guthi was split when numbers of population increases in both sides or there may be some problems in socio-cultural adaptation between the two segments.

The formation of Najing Bhimsen guthi and its history can be taken as an example. The Najing village is composed by Newar, Chhetri and Sherpa communities. The Newars and the Chhetris had a common guthi till fifteen years ago. There were 30 households as members in the guthi. Although the Newar and the Chhetris culture and tradition differ and there was a strong sense of caste principles, they were adjusted to each other. For example there were separate kitchens for the Newar and the Chhetris in rituals and celebrations. Later they split the guthi. Now, the Newars and the Chhetris have their separate guthi and samaj (Chhetri named it samaj).

Separation of guthi or the inclusion and exclusion may be interpreted differently. The first cause of separation is the household growth and population increase in both sides. As the population increased and the number of households became sufficient to conduct their rituals and celebration in their own caste, they may decide to separate it. The second was the debate on food and drinks. The Newars and the Chhetris consume different food items in their rituals and celebration. For example, the Newars mostly preferred buff and beaten rice instead of rice which the Chhetris preferred. And third, influence of identity politics in Nepal. However, the problem in cultural adaptation and acculturation is the prime foci of the exclusion of the non-Newars members in the guthi.

In the case of Newars, new membership is given to the separated sons after marriage but exclusion from the guthi is unthinkable till death or emigration. Hence, the guthi binds the 
Newars together in one hand and in other hand; guthi is the joint power through which the Newars perform their rituals and celebrations. It is the guthi that enabled the Newars for inter-cultural adaptations and sometimes it supports for bargaining the power with other caste and ethnic communities.

\section{The nature of acculturation}

The Newars actively participate in social, cultural and political activities. Lakhe jatra is one and only jatra perform in Dorpu-Salleri bazar that not only entertain the non-Newars but also supports to identify the Newars culturally different than others. However, the Newars are highly acculturated. The Newars do not have their own ritual expert such as purohit. Most of the rituals and rites are performed by the Brahmin purohit. Interestingly, the old Newars work as ritual experts in some of the festivals and rituals. The life-cycle rituals are performed by Brahmin purohit. The Newars of the municipality lost their mother tongue 'Nepal Bhasa'. Although national census stated that 0.61 per cent Newars use their mother tongue in Solukhumbu district (CBS, 2012), I never observed the Newars speaking Nepal Bhasa. When I asked on these matters, 58 years old Newar from Najing stated:

We do not speak Nepal Bhasa because my parents and relatives also did not speak in our mother tongue. We do not have Newar priest; Brahmin priest conducts our birth and death rituals. But we do not call Brahmin priest in marriage ceremony. We perform it by our own ritual experts, especially by the oldest people (I. K. Shrestha, personal communication, July 7, 2020).

It is obvious that the Newars are highly acculturated and adopted the Brahmin and Chhetri culture (Shrestha, 2011) but in most of the rituals and rites they mix their own ritual processes which they knew. Most of the Newars of the municipality can communicate in Sherpa language. They even take part in different Buddhist puja and ceremony as jindag (sponsors) but they did not imitate Sherpa culture and tradition like the Newars lived in the Khumbu region (Haimendorf, 1964; Shrestha, 2018). It may be because the Hindu religion was the state religion which had directly influenced the Newars or the domination of the ruler's ideology compelled the Newars to adapt it. Moreover, such an acculturation is the process of adjusting the Newars in new socio-cultural environment of the multiple caste and ethnic people.

\section{The Newars in politics}

The Newars actively participated in the national and local politics. Recently, there is a Newar (Rajbhandari) elected as Member of Parliament in provincial assembly. One Newar (Shrestha) became the member of District Coordination Committee and two others are 
elected as Ward Chairpersons. Two Newars were elected as chairpersons of Garma Village Development Committee in the local elections of 2048 B.S. and 2054 B.S. Some Newars are actively taking part in the party politics.

This shows that the Newars of Solu-dudhkunda Municipality have comparatively living their prosperous lives. They are socially, culturally and politically active. They have an access on education and administration. Then the question comes, why the Newars remigrated to the Kathmandu Valley and elsewhere in Nepal? There is a need of future research to reveal and analyze such issues.

\section{Conclusion}

The history and the causes of migration of the Newars in Solukhumbu district are controversial. The Newars of Solu-dudhkunda Municipality have different histories and genealogies which concludes their differences in origin, ancestors and reasons of their migration. However, we are very much near to some of the arguments in regard to the Newars' migration. The trade is probable cause of their migration. Even today, some Newars moves from Okhaldhunga and Khotang to different parts of Solukhumbu district for seasonal haat bazar. Probably, the Newars in the past visited for trade and made their settlement permanent. They settled marrying with the women in Solukhumbu. There are some cases as evidence to support the arguments.

The socio-cultural adaptation for the new comers is not an easy work. That's why the Newars acculturated but interestingly did not abandon their caste and ethnic based rituals and rites. They formed the guthi for their social, cultural, economic and political adaptation. Hence, a new form of Newar culture developed in the hills. The Newars are in minority today and it was in the past too. It is obvious that the acculturation process takes place from dominant group to the dominated one. The Newars who lived in the larger Sherpa community not only learned Sherpa language but also actively participate in special Buddhists' ceremony as a jindag. Similarly, Newar living with Chhetri community adopted the Chhetri rituals and rites and participated in many Hindu rituals and rites. But the Newars of the municipality is not totally assimilated being Newar Sherpa as in Khumbu (FuererHaimendorf, 1964).

The inclusion and exclusion from the guthi and making new guthi after its split is also a process of their socio-cultural, economic and political adaptation. The split of guthi is directly linked to caste and ethnic based identity politics. It is because after the split of the guthi the inter community communication and cooperation is still strong and continued. 
However, the new generations of the Newars are out-migrating from the district to other parts of Nepal. Educated and capable youth rarely stay at the villages like the youths of other caste and ethnic groups. These situations may lead the Newars community extinct from Solu-dudhkunda Municipality, the sooner or the later.

\section{References}

Adhikari, J. (2008). Changing livelihoods: Essays on Nepal's development since 1990. Martin Chautari, Thapathali, Kathmandu, Nepal

Bista, D. B. (1967). People of Nepal. Ratna Pustak Bhandar, Kathmandu, Nepal

Bista, D. B. (2030 B.S.). Sabai jatko phulbari. Sajha Prakashan, Lalitpur, Nepal

Bista, D. B. (1980). Nepalis in Tibet. Contributions to Nepalese studies, 8(1), 1-19.

CBS. (2012). National Population Census 2011, VDC and Municipality by caste/ ethnic group: Solukhumbu. Kathmandu , Nepal: Central Bureau of Statistics, Government of Nepal.

Child, G. \& Choedup, N. (2019). From a trickle to a torrent: Education, migration, and social change in a himalayan valley of Nepal. Oakland: University of California Press.

Furer-Haimendorf, C. (1964). The Sherpas of Nepal. Buddhist Highlanders, Sterling Publishers Pvt. Ltd., New Delhi.

Nepali, G. S. (1965). The Newars: An ethno-sociological study of a himalayan community. Himalayan Book sellers, Kathmandu, Nepal.

Hamilton, F. B. (1819). An account of the kingdom of Nepal. Asian Educational Services, New Delhi, India.

Harris, M. (1978). Cows, pigs, wars and witches: The riddle of culture. Vintage books, New York, USA.

Heide, S. (2001). Some aspects of migration, mobility and the democracy movement among the Thakalis-effects of cultural change and the danger of cultural loss. In Heide, S. \& Hoffman, T (Eds.), Aspects of migration and mobility in Nepal (pp. 73-113). Ratna Pustak Bhandar, Kathmandu, Nepal.

Hoffman, T. (2001). Out-migration pattern of Solu-Khumbu district. In Heide, S. \& Hoffman, T (Eds.), Aspects of migration and mobility in Nepal (pp. 115-127). Ratna Pustak Bhandar, Kathmandu, Nepal.

Gurung, H. (2001). Highlanders on the move: The migration trend in Nepal. In Heide, S. \& Hoffman, T (Eds.), Aspects of migration and mobility in Nepal (pp. 11-42). Ratna Pustak Bhandar, Kathmandu, Nepal.

Lewis, T. T.\& Shakya, D.R. (1988). Contributions to the history of Nepal: Eastern Newar diaspora settlements CNAS, Journal 15(1), 25 - 65.

Lewis, T. T. (1989). Newar and Tibetans in the Kathmandu Valley ethnic boundaries and religions history. Journal of Asian and African Studies (38), 31- 57.

Lewis, T. T. (1993).Tibetan trade and the domestication of "simhalasar thabahu avadana". History of Religions 33 (2), 135-160. 
Pradhan, S. (2018). Dynamics of ehi ceremony among the Newars of district Darjeeling. (Mphil Dissertation). Department of Anthropology, school of Human Sciences, Sikkim University, India.

Rajbhandari, D. (2013). The genealogy of the Rajbhandari. Rajani Prakashan, Lalitpur, Nepal.

Rappaport, R. A. (1968). Pigs for the ancestors: Ritual in the ecology of a New Guine people. Yale University Press, London.

Robertson, T. (May 2, 2020). Smallpox, politics and power in Kathmandu. www.nepalitimes.com/opinion/smallpox-politics-and-power-in-kathmandu, retrieved, July 13, 2020.

Sakasita, J. (July 12, 2020). Newarka pida yesta pani thiye, thaha chha? www.sancharnepal.com/content/18863, retrieved, July 12, 2020.

Schneller, M. (2001). The impact of migration on the stability of the international system. In Heide, S. \& Hoffman, T (Eds.), Aspects of migration and mobility in Nepal (pp. 1-9). Ratna Pustak Bhandar, Kathmandu, Nepal.

Sharma, J. L. (2039 B.S.). Hamro samaj ek addhyan. Sajha Prakashan, Lalitpur, Nepal.

Shrestha, B.G. (2006). Ritual and identity in the diaspora: The Newars in Sikkim. Bulletin of Tibetology (25), 25-54.

Shrestha, B.G. (2015). The Newars of Sikkim: Reinventing languages, culture, and identity in the diaspora. Vajra Books, Kathmandu, Nepal.

Shrestha, K. N. (2011). Changing traditions of the Newars: An analysis on lifecycle rituals. Samaj Journal of Sociology/anthropology, 4, 67-72.

Shrestha, K. N. (2018). Tourism development: Power structure and crisis of culture. (PhD Dissertation). Faculty of Humanities and Social Sciences, Tribhuvan University, Nepal.

Shrestha, K. N. (2020). Tourism and transformation: Changing livelihood practices of mountain dwellers. Journal of Tourism and Himalayan Adventures: An International Research Journal 2, 57-72.

Shrestha, N. R. (2001). The political economy of land, landless and migration in Nepal. Nirala publication, New Delhi, India.

Shrestha, T. N. (2010). Nepalka Newarharu: Pahichan ra pristhabhumi. Anusandhan tatha Vikas Sanstha, Kathmandu, Nepal.

Tuladhar, P, Joshi, S. Shrestha, M., Shrestha, O., Maharjan, T., Shrestha, I., Bajracharya, B., Joshi, R., Kansakar, S., Shrestha, R., Maharjan, J., Shakya, S. (2011). Newar jatiko chinari. Adibasi Janajati Utthan Rastriya Prathistan, Lalitpur, Nepal.

Wright, D. (1877). History of Nepal. Rupa \&Co., New Delhi, India. 